\title{
Komunikasi Ekspresif Estetik Karya Seni
}

\author{
Pangeran Paita Yunus \\ Universitas Negeri Makassar, Makassar, Indonesia \\ pangeranpaita69@gmail.com \\ Aesthetic Expressive Communication of Artworks
}

\begin{abstract}
Art as an aesthetic expression is the result of an artist's inner expression that appears in art through the medium and the tools that it uses. Someone who has a soul impulse or depressed condition, then will try to release those feelings by doing something. This kind of activity is meant by expressions. Someone expresses something both verbally and non-verbally intends to convey something message to others. In this context, expressions can be referred to as communication activities. In art activities, the communication process takes place between artists as messengers through their artworks that are reflected through visible symbols or symbols. That is, works of art in the form of symbolic information as an aesthetic expression of an artist will be accepted by the appreciator and then there will be a dialogue between art work and the appreciator
\end{abstract}

Keywords: communication; aesthetic expressive; artworks.

\section{ABSTRAK}

Seni sebagai ekspresi estetik merupakan hasil ungkapan batin seorang seniman yang tampak pada karya seni lewat medium dan alat yang digunakannya. Seseorang yang memiliki dorongan jiwa atau kondisi tertekan, maka akan berusaha untuk melepaskan perasaan tersebut dengan melakukan sesuatu. Kegiatan semacam ini yang dimaksud dengan ungkapan. Seseorang mengungkapkan sesuatu baik secara verbal maupun non-verbal bermaksud untuk menyampaikan sesuatu pesan kepada orang lain. Dalam konteks ini, ungkapan dapat disebut sebagai kegiatan berkomunikasi. Dalam kegiatan seni, proses komunikasi terjadi antara seniman sebagai penyampai pesan lewat karya seninya yang tercermin lewat lambang-lambang atau simbol-simbol yang tampak. Artinya, karya seni berupa informasi simbolis sebagai ekspresi estetik seorang seniman akan diterima oleh penghayat dan selanjutnya akan terjadi dialog antara karya seni dengan penghayatnya.

Kata Kunci: komunikasi, ekspresif estetik, karya seni 


\section{PENDAHULUAN}

Karya seni lahir berkat adanya kegiatan manusia. Karya seni dilahirkan oleh dan dari manusia. Keberadaan karya seni disadari atau tidak dilatarbelakangi oleh gambaran tentang adanya manusia lain, yang diharapkan mampu dan bersedia menjadi penikmat. Manusia tak terkecuali seniman sebagai makhluk sosial, pada dasarnya membutuhkan kehadiran orang lain yang dapat mengapresiasi karya seni yang diciptakannya. Seni itu adalah salah satu hasil budaya manusia. Lahir karena dicipta dengan melalui tiga tingkatan aktivitas yakni: Pengamatan terhadap kualitas material warna, tekstur dan reaksi fisis lainnya; penyusunan dari hasil pengamatan menjadi bentuk-bentuk tertentu dan terakhir dimanfaatkan susunan tadi untuk diekspresikan secara emosional yang menghasilkan rasa nikmat atau rasa puas (Yunus, 2014: 17).

Sebagai makhluk berbudaya, manusia mengekspresikan pengalamanpengalamannya melalui simbol. Inilah yang kemudian menjadi pijakan Ernest Cassirer (1990) menyebut manusia sebagai animal symbolism. Pada tataran ini, seni mengambil peran sebagai media ekspresi. Jadi karya seni sesungguhnya bisa dilihat sebagai perpaduan antara wujud lahiriah yang bisa diamati dan perasaan terhadap nilai tertentu yang berdimensi rohaniah. Wujud lahiriah mengejawantahkan sikap batin terhadap nilai tertentu. Begitu pula halnya dengan sikap batin itu akan memperoleh wujudnya yang harmonis secara langsung. Proses eksternalisasi secara langsung ini oleh Sahman (1993: 29) disebut ekspresi simbolik.

Seorang seniman yang melakukan kegiatan kreatif, akan mengalami perjumpaan atau kontak dengan alam semesta secara umum. Dari perjumpaan ini akan memperlihatkan dua dimensi, yang subjektif yaitu yang mengacu pada pencipta dan yang objektif yaitu alam semesta yang menjadi sasaran penjumpaan. Alam semesta yang menjadi sasaran penjumpaan bukanlah mutlak objektif, akan tetapi diwarnai oleh visi penciptanya. Alam semesta yang dimaksud bukanlah alam semesta sebagaimana adanya, akan tetapi alam semesta sebagaimana dilihat sang seniman, dunia yang sudah tersubjektivasi untuk menghasilkan karya yang baru atau orisinil. Inilah yang disebut dengan proses kreatif.

Proses kreatif seniman akan menghasilkan karya seni yang memiliki kualitas keindahan sebagai wujud inderawi yang dapat membangkitkan pengalaman perasaan tertentu pada seseorang. Kualitas keindahan karya seni menurut Sumardjo (2000: 193) mengandung kualitas yang menyenangkan secara inderawi dan membahagiakan secara rohani.

Kualitas atau nilai keindahan sebuah karya seni pada dasarnya dapat dibedakan antara nilai intrinsik dan nilai ekstrinsik seni. Nilai intrinsik seni merupakan wujud seni yang terindera dan dapat memberikan kepuasan keindahan bagi yang mengamatinya. Nilai ini terdiri dari nilai bentuk seni yang terdiri dari bahan seni dan cara penyusunan (struktur seni) bahan tadi. Struktur dimaksud adalah bentuk harmoni, kesatuan, keselarasan, keseimbangan, dan lain-lain. Sedangkan nilai ekstrinsik seni disebut juga isi seni. Nilai 
ekstrinsik ini dimaksudkan bahwa setiap karya seni yang diciptakan seniman memiliki maksud tertentu atau ingin menyampaikan 'sesuatu' kepada orang lain. Ingin berkomunikasi dengan publik seni. Kualitas isi ini terdari dari perasaan, intuisi, dan informasi, serta nilainilai hidup.

Dua nilai yang dikandung karya seni inilah yang menjadi masalah ketika terjadi proses komunikasi antara seniman, karya seni, dan penghayat. Bahkan buntu bagi orang lain. Ada yang menekankan nilai intrinsiknya dan ada yang menekankan nilai ekstrinsiknya. Masalah komunikasi nilai seni inilah yang akan dibahas dalam tulisan ini.

\section{KOMUNIKASI EKSPRESI ESTETIK}

Seni sebagai ekspresi estetik merupakan hasil ungkapan batin seorang seniman yang tampak pada karya seni lewat medium dan alat yang digunakannya. Seseorang yang memiliki dorongan jiwa atau kondisi tertekan, maka akan berusaha untuk melepaskan perasaan tersebut dengan melakukan sesuatu. Kegiatan semacam ini yang dimaksud dengan ungkapan. Seseorang mengungkapkan sesuatu baik secara verbal maupun non-verbal bermaksud untuk menyampaikan sesuatu pesan kepada orang lain. Dalam konteks ini, ungkapan dapat disebut sebagai kegiatan berkomunikasi. Hal tersebut sejalan dengan pendapat Robbins dan Jones (1995: 1) yang menyatakan bahwa komunikasi adalah suatu tingkah laku, perbuatan atau kegiatan penyampaian atau pengoperan lambang-lambang yang mengandung arti dan makna atau perbuatan penyampaian suatu gagasan atau informasi dari seseorang kepada orang lain.

Dalam kegiatan seni, proses komunikasi terjadi antara seniman sebagai penyampai pesan lewat karya seninya yang tercermin lewat lambang-lambang atau simbol-simbol yang tampak. Artinya, karya seni berupa informasi simbolis sebagai ekspresi estetik seorang seniman akan diterima oleh penghayat dan selanjutnya akan terjadi dialog antara karya dengan penghayatnya.

Proses komunikasi seni antara seniman dengan penghayat akan selalu terjalin selama kehadiran karya seni masih dibutuhkan oleh manusia. Sebuah komunikasi seni selalu dilandasi dengan berbagai pengalaman dari kehidupan batin yang berbeda, dan mampu menciptakan makna, bisa pula berupa 'pemaknaan baru' terhadap karya yang diapresiasi, yang juga tidak perlu serangam, namun tetap memberikan kemungkinan hadirnya suatu kepuasan pengalaman yang mendalam. Orang dapat merestruktur ekspresi maupun isi pesan mengikuti kemungkinan-kemungkinan dan kapasitas pengkombinasiannya yang dinamis. Proses komunikasi dapat menciptakan semacam diskursus baru (new discourse), yaitu ketika ekspresi atau isi komunikasi betul-betul baru dan tak-terumuskan (underfinable) lewat kode yang ada (Eco, 1979: 188).

Terjadinya dialog antara seniman, karya seni, dan penghayat, maka seni merupakan ekspresi estetik sekaligus sebagai alat komunikasi. meskipun karya seni merupakan ekspresi pribadi setiap seniman, namun setelah karya itu lahir, maka karya tersebut akan menjadi bentuk yang siap untuk dinikmati oleh publik seni. 
Dalam konteks Indonesia, komunikasi ekspresi estetik tidak sekadar keunikan pesan atau makna dari sebuah ekspresi seni, namun di dalamnya menyangkut etika dan nilai-nilai masyarakat yang mendukung seni tersebut (Jaeni, 2012: 164). Bahkan menurut Chandrasekhar (dalam Jaeni, 2012: 164), mengungkapkan bahwa komunikasi estetik terjadi karena relasi harmonis antara unsur-unsur keindahan seni dengan kecerdasan, perasaan, dan pengalaman individu dalam lingkungannya. Pendapat ini mempertegas bahwa rasa keindahan (estetik) timur dan barat, memang jauh berbeda, sekalipun ada klaim tentang globalisasi yang kadang menyeragamkan unsur-unsur estetik tersebut.

Menurut Sumardjo (2000: 188-189) bersatunya unsur-unsur komunikasi seni yakni seniman, benda seni dan publik seni di dalam suatu 'peristiwa seni' akan melahirkan apa yang disebut pengalaman seni. Benda seni yang diciptakan oleh seniman akan diterima nilainya oleh publik seni dalam konteks sosio-budayanya, dan ini menandakan ada komunikasi seni yang sehat. Lebih lanjut menurut Sumardjo (2000: 188) dalam masyarakat yang tertutup, konteks sosio-budaya ini relatif masih utuh dan sama untuk semua warganya, sehingga komunikasi nilai seni tidak mengalami hambatan yang berarti. Berbeda halnya dalam masyarakat majemuk dan terbuka seperti masyarakat Indonesia sekarang, komunikasi seni dapat menjadi persoalan, salah satu penyebabnya karena konteks sosiobudaya antara seniman dan publik seni mungkin amat berbeda.

Unsur-unsur komunikasi seni di Indonesia belum menyatu dalam suatu sistem yang baku. Dan ini mengakibatkan terjadinya berbagai konteks pada unsur seniman dan unsur masyarakat. Nilai seni yang dituju masyarakat modern Indonesia adalah nilai seni modern Indonesia. Dan karena konteks sosio-budaya masyarakat modern sendiri belum jelas dan belum terbentuk secara utuh, maka persoalan nilai seni tetap menjadi masalah dalam komunikasi seni.

Untuk mengatasi kesenjangan tersebut, dapat dilakukan melalui model pendidikan nilai seni yang terkonsep dengan matang dan baik, melalui lembaga pendidikan formal maupun non-formal. Menurut hemat penulis, hanya melalui pendidikanlah nilai-nilai seni dapat ditanamkan. Pendidikan seni yang sama akan melahirkan sistem nilai yang sama pula. Dan sistem nilai yang sama akan melancarkan komunikasi seni (Sumardjo, 2000: 190).

Pengalaman estetik dapat dialami oleh setiap manusia, tapi tidak banyak yang memiliki kemampuan memindahkannya ke dalam karya seni. Sebagian orang hanya bisa menikmati pengalaman estetiknya. Sedang oleh perupa (pelukis, pematung, dan lain-lain), pengalaman tersebut dapat diubah menjadi pengalaman ekspresif artistik ketika menciptakan karya seni. Sementara itu, untuk membuat efek artistik yang berbeda, para perupa menciptakan teknik khusus yang belum dijelajahi perupa lain. Selanjutnya karya yang tercipta perlu ditampilkan untuk diapresiasi atau dihayati oleh masyarakat. Interaksi antara penikmat seni dan seniman sangat penting karena dapat menimbulkan suasana komunikasi bahkan sampai pada kritik yang bermanfaat.

Karya seni sebagai akhir dari suatu proses yang kita sebut aktivitas kreatif. Proses mencipta karya seni memiliki tahapan-tahapan, dimulai dari adanya ide imajinatif yang diolah di benak, kemudian diwujudkan menjadi karya seni rupa yang artistik. Menurut Salam 
(2020: 12) seseorang yang memiliki ide imajinatif dapat disebut sebagai manusia imajinatif, dan jika ia mampu mewujudkan imajinasinya tersebut menjadi karya nyata, ia dapat disebut sebagai manusia kreatif.

Jikalau kita melihat dan mencermati karya-karya perupa yang tampil dalam berbagai kegiatan pameran sebagai upaya mengiringi wacana apresiasi seni masyarakat sebagai bentuk komunikasi antara seniman, karya seni dan penikmatnya, maka pada prinsipnya cara seniman dalam mengkomunikasikan Ide/gagasannya menjadi sebuah karya seni, memiliki dua kecenderungan. Kecenderungan pertama adalah ciri karya ke arah penggambaran realistik yang diistilahkan kutub yang masih mengejar kekuatan bentuk dan struktur serta kemampuan untuk mengkoordinasikan antara mata dengan tangan. Konstruktivisme, Kubisme, Abstrak Formalisme, minimal art, earth art, dan neoplastisisme adalah aliran-aliran yang sangat kental dengan kebentukan.

Penggambaran realistik merupakan hasil karya yang paling umum dikenal. Kutub ini memandang dunia sebagai sesuatu yang nyata (tanpa ilusi). Seniman penganut kutub ini ingin menciptakan karya seni yang nyata dan menggambarkan sesuatu yang benar-benar ada dan kasat mata. Dalam perjalanannya kemudian, gambaran realistik pada karya-karya itu dianggap 'alat' yang mampu mewakili gambaran realitas yang dimaksud para seniman. Dengan demikian, karya seni sebagai ekspresi estetis seolah-olah adalah label - lebih bersifat visual dari pada verbal yang mewakili dan menjelaskan berbagai pengalaman hidup dan realitas. Biasanya seniman yang menganut kutub ini dalam mengkomunikasikan ide/gagasannya menunjukkan ciri/karakter dengan kecendrungan: tema penggambaran citra manusia, tema gambaran kehidupan, serta tema penjelajahan gagasan yang menghasilkan gambaran yang melampaui citra realistik (Zaelani, 2007).

Berikut contoh analisis karya seni lukis yang memiliki kecendrungan realistik di bawah ini:

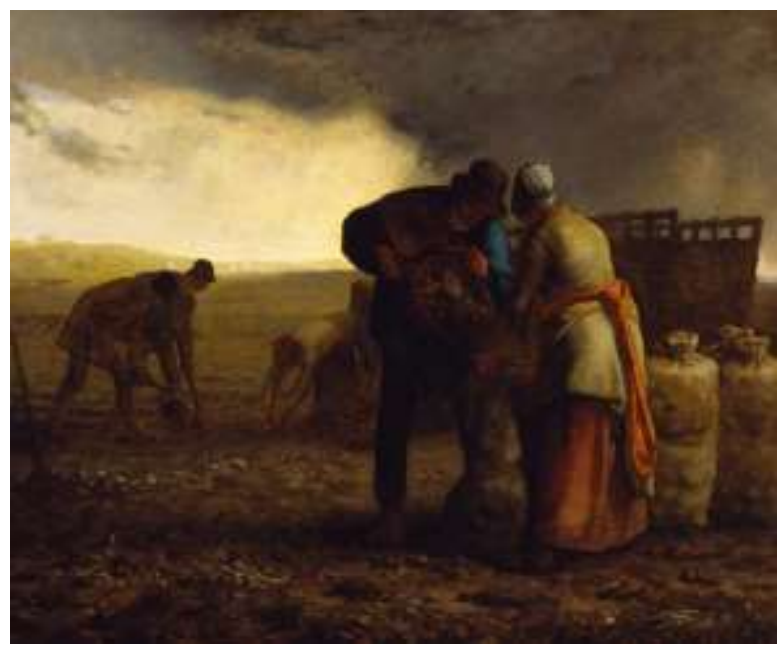

Gambar 1. The Potato Harvest (Panen Kentang) Karya Jean-Francois Millet Sumber: https://serupa.id/wp-content/uploads/2018/03/contoh-aliran-realisme-thepotato-harvest-Jean-francois millet-serupa-id.jpg 
Pelukis Jean-Francois Millet menggambarkan secara realistis apa yang terjadi di tengah kehidupan masyarakat. Lukisan ini menggambarkan para petani kentang dalam salah satu adegan keseharian mereka ketika sedang bekerja. Lukisan ini menunjukkan betapa kerasnya pekerjaan yang mereka lakukan untuk bertahan hidup. Adegan yang diambil spesifiknya adalah ketika para petani sedang memanen kentang. Mereka tidak berhenti bekerja hingga matahari mulai tenggelam. Millet mengangkat harkat derajat kaum petani sebagai fondasi dari kehidupan sosial yang langsung berhubungan dengan kebutuhan utama manusia, yaitu bahan makanan. Lukisan tersebut menggambarkan kondisi kehidupan sosial masyarakat pada masa itu sesuai apa adanya.

Kecenderungan karya yang kedua adalah karya berusaha mengejar kekuatan ekspresi dan kekuatan abstraksi bentuk. Pada kutub ini, setidaknya kita bisa menemukan dua arah kecenderungan strategi abstraksi bentuk, yakni abstraksi bentuk tema figur manusia dan abstraksi bentuk non-obyek. Untuk menilai karya seperti ini terlebih dahulu memahami konsep atau filosofi yang melatar-belakangi penciptaan sebuah karya. Kriteria yang cocok digunakan untuk memahami karya tersebut adalah aspek kekuatan keekspresifan, keharmonisan, keartistikan, dan lain-lain.

Bagi perupa yang menganut paham ekspresionis berpandangan bahwa perasaan estetik tidak hanya berdasarkan indera penglihatan, namun juga berdasarkan pengalaman batin. Perupa biasanya melukiskan objek yang mengesankan dengan perasaan yang bergejolak dari sudut pandang subjektif. Kemudian, perupa yang menganut pada kekuatan abstraksi bentuk berpandangan bahwa seorang perupa harus berusaha untuk melepaskan diri dari sensasi atau asosiasi figuratif suatu objek. Menurut Salam (2020: 95) ciri utama karya seni rupa corak ini adalah wujud yang digambarkan terbebas dari ilusi atas bentuk alam, dengan kata lain tidak berhubungan bentuk apa pun yang pernah kita lihat (non figuratif), meskipun bila diamati secara saksama terkadang terkesan menyerupai sesuatu.

Dalam komunikasi seni, salah satu sumber rumitnya dialog antara karya seni dengan penghayat, terletak pada apresiasi corak karya yang memiliki kecenderungan abstraksi bentuk. Mengapa demikian, karena tingginya subjektivitas perupa dalam mengorganisasi atau menyusun dan mengatur bahan seninya sesuai dengan keinginannya. Setiap perupa berupaya mencari dan menemukan cirinya yang unik dan original. Di sinilah letak kerumitan komunikasi seni tersebut. Seorang penghayat yang mampu menangkap struktur sebuah karya, maka ia akan mampu berkomunikasi dengan karya tersebut. Dan cara setiap penghayat dalam menangkap struktur sebuah karya seni justru bisa berbeda-beda, sangat tergantung pada pengetahuan dan pengalaman penghayat. Namun demikian, untuk menangkap nilai yang terkandung pada karya seni yang memiliki kecenderungan abstraksi bentuk, kata kuncinya ada pada bagaimana seorang penghayat harus bisa memahami struktur isi yang membangun karya tersebut, apa yang diungkapkan, pikiran dan perasaan serta pengalaman apa yang ingin disampaikan sang perupa.

Biasanya seniman yang menganut kutub ini dalam mengkomunikasikan ide/gagasannya menunjukkan strategi abstraksi bentuk dengan kecenderungan pada abstraksi bentuk pada tema figur manusia dan abstraksi bentuk dalam penggambaran materi subjek non-objek.

Berikut contoh analisis karya seni lukis yang memiliki kecendrungan abstraksi bentuk di bawah ini, 


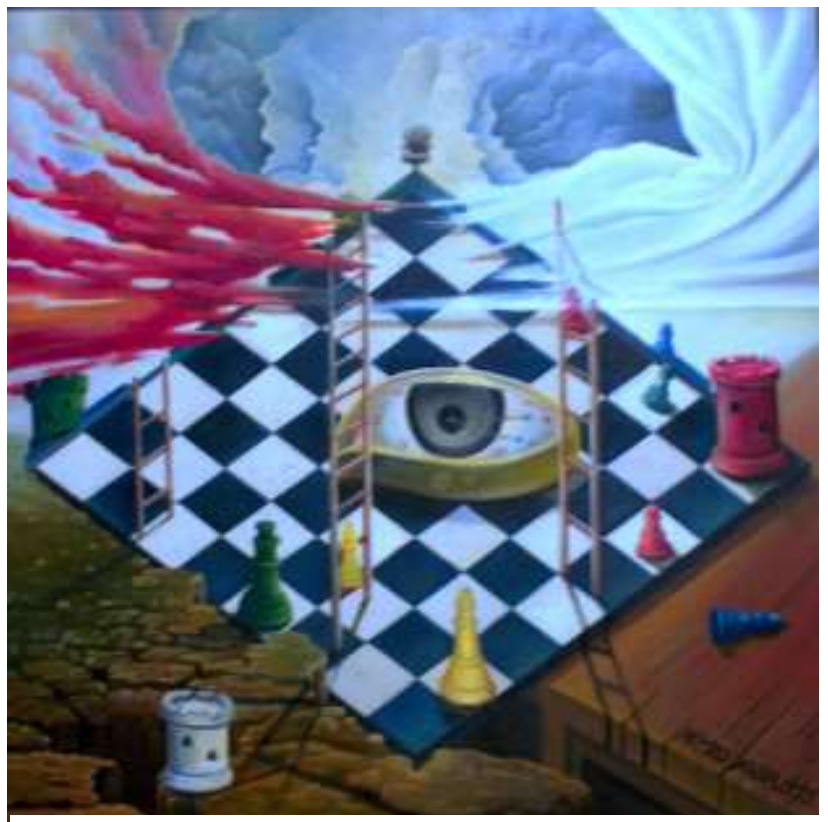

Gambar 2. Karya lukis La Kadir "Catur Politik" (1999)

Pada lukisan di atas, yang menjadi materi subjeknya adalah papan catur dengan pion-pionnya dan sejumlah figur lainnya. Yang menjadi figur sentral berupa papan catur yang diletakkan di salah satu sisi sebuah meja. Sisi lain papan catur tersebut berada di bibir jurang. Pada salah satu sisi bagian atas papan catur terdapat sebuah kursi 'mirip kursi yang biasa diduduki seorang pejabat. Di atas papan catur tampak beberapa pion-pion catur yang berwarna kuning, merah dan hijau, tiga buah tangga dan sebuah mata. Warna merah dan putih mendominasi sebagai awan, dan pada latar belakang lukisan tersebut tampak dua figur kepala manusia yang dikaburkan seolah-olah bagian dari awan. Pada setiap sisi papan catur, terdapat pion-pion yang digambarkan tidak lagi berada di atas papan catur.

Karya ini dibuat oleh La Kadir pada tahun 1999, ketika bangsa Indonesia mengalami hiruk pikuk kondisi sosial politik yang tidak menentu. Pada masa itu, persaingan tiga partai besar yakni Golongan Karya (Golkar), Partai Persatuan Pembangunan (PPP), dan Partai Demokrasi Indonesia (PDI) semakin memuncak. Kesimpangsiuran kondisi sosial politik ini sebagai imbas yang terjadi di ujung dekade 1990-an yang melahirkan 'Gerakan Reformasi'.

\section{SIMPULAN}

Terjadinya dialog antara seniman, karya seni, dan penghayat, maka seni merupakan ekspresi estetik sekaligus sebagai alat komunikasi. meskipun karya seni merupakan ekspresi pribadi setiap seniman, namun setelah karya itu lahir, maka karya tersebut akan menjadi bentuk yang siap untuk dinikmati oleh publik seni. untuk menangkap nilai yang terkandung pada karya seni yang memiliki kecenderungan abstraksi bentuk, kata kuncinya ada pada bagaimana seorang penghayat harus bisa memahami struktur isi yang membangun karya tersebut, apa yang diungkapkan, pikiran dan perasaan serta pengalaman apa yang ingin disampaikan sang perupa. Saran, untuk terjadinya komunikasi seni yang baik, diharapkan adanya edukasi yang dapat dilakukan melalui model pendidikan nilai seni yang terkonsep dengan matang dan baik, melalui lembaga pendidikan formal maupun non-formal. 


\section{DAFTAR PUSTAKA}

Cassirer, E. (1990). Manusia dan Kebudayaan: Sebuah Esay tentang Manusia, diterjemahkan oleh Alois A. Nugroho. Jakarta: Gramedia.

Eco, U. (1979). A Theory of Semiotics. Bloomington: Indiana University Press.

Jaeni. (2012). Komunikasi Estetik dalam Seni Pertunjukan Teater Rakyat Sandiwara Cirebon. Jurnal Seni \& Budaya Panggung Vol. 22, No. 2, April - Juni 2012: 160 - 168.

Robbins, J.G \& and Jonse, B.S. (1995). Komunikasi yang Efektif: untuk Pemimpin, Pejabat dan Usahawan. Alibahasa R. Turman Sirait. Jakarta: Pedoman IImu Jaya.

Sahman, H. (1993). Mengenal Dunia Seni Rupa: tentang Seni, Karya Seni, Aktivitas Kreatif, Apresiasi, Kritik dan Estetika. Semarang: IKIP Semarang Press.

Salam, S., dkk. (2020). Pengetahuan Dasar Seni Rupa. Makassar: Badan Penerbit Universitas Negeri Makassar.

Sumardjo. J. (2000). Filsafat Seni. Bandung: Penerbit ITB.

Yunus, P.P. (2014). Apresiasi Seni. Makassar: Prince Publishing.

Zaelani, R.A. (2007). 'Demi ma(s)sa: Pameran Seni Rupa Nusantara 2017. Katalog. Jakarta: Galeri Nasional Indonesia.

Contoh-aliran-realisme-the-potato-harvest-Jean-francois_millet-serupa-id.jpg. diakses dari: https://serupa.id/wp-content/uploads/2018/03 pada 1 Mei 2020 